\title{
TINGKAT KEPUASAN DAN LOYALITAS KONSUMEN XYZ DI JABODETABEK
}

\section{CUSTOMER SATISFACTION AND LOYALTY OF XYZ'S CUSTOMERS IN JABODETABEK}

\author{
Rizki Fatiha*, Agriani Hermita Sadeli, Erna Rachmawati, Lucyana Trimo \\ Universitas Padjadjaran, Jl. Raya Sumedang-Bandung Km. 21, Jawa Barat \\ *E-mail: rizkifatiha24@gmail.com \\ (Diterima 08-04-2021; Disetujui 03-06-2021)
}

\begin{abstract}
ABSTRAK
Kemajuan teknologi yang pesat menyebabkan akses informasi untuk memenuhi makanan sehat saat ini bukan lagi menjadi hal yang rumit. Penjual dan pembeli dapat berinteraksi langsung melalui dunia maya tanpa harus pergi ke luar rumah. Banyaknya pilihan e-commerce dan marketplace membuat persaingan antar ritel semakin ketat. XYZ merupakan salah satu e-commerce yang menjual sayur dan buah. Ketatnya persaingan di tengah pandemi menuntut XYZ untuk terus melakukan peningkatan dalam kualitas pelayanan dan kualitas produknya. Penelitian ini bertujuan untuk mengukur tingkat kepuasan dan tingkat loyalitas konsumen XYZ di Jabodetabek. Penelitian ini dilakukan dengan menyebarkan kuesioner pada konsumen XYZ secara online melalui direct message. Desain penelitian yang digunakan adalah desain kuantitatif dengan teknik penelitian explanatory survey. Jumlah sampel yang digunakan pada penelitian ini adalah 96 sampel dengan responden penelitian yaitu konsumen yang pernah berbelanja sayur dan buah di XYZ dan berdomisili di Jabodetabek. Metode analisis yang digunakan adalah analisis deskriptif, Customer Satisfaction Index (CSI), dan Importance Performance Analysis (IPA). Hasil penelitian menunjukkan bahwa konsumen XYZ di Jabodetabek sangat puas terhadap pelayanan yang diberikan XYZ. Konsumen XYZ di Jabodetabek juga memiliki tingkat loyalitas yang sangat tinggi.
\end{abstract}

Kata kunci: e-commerce, Kepuasan, Loyalitas, CSI, IPA

\begin{abstract}
Rapid technological advances allow access to information about healthy food nowadays is no longer an important issue. Sellers and buyers can interact directly through the internet without having to go out of the house. The large number of e-commerce and marketplace options makes competition between retailers even tighter. XYZ is one of the many e-commerce that sells vegetables and fruits. The intense competition amid a pandemic demands XYZ to continue making improvements in service quality and product quality. This study aims to measure the level of satisfaction and level of consumer loyalty of XYZ in Jabodetabek. This research was conducted by distributing questionnaires to XYZ consumers via Instagram's direct message. The research used a quantitative design with an explanatory survey as the technique of the research. The number of samples used in this study was 96 samples with respondents who happened to shop for vegetables and fruits from XYZ and live in Jabodetabek. Data analysis that was used in the research was descriptive, Customer Satisfaction Index (CSI), and Importance Performance Analysis (IPA). The results showed that XYZ consumers in Jabodetabek were very satisfied with the services provided by XYZ. They also tend to have a very high level of loyalty.
\end{abstract}

Keywords: e-commerce, Satisfaction, Loyalty, CSI, IPA 


\section{PENDAHULUAN}

Kasus positif pertama virus Corona di Indonesia diumumkan sejak 2 Maret 2020. Kasus pertama ini berasal dari warga Depok, Jawa Barat. Hal ini cukup meresahkan masyarakat terlebih kota Depok yang merupakan bagian dari Jabodetabek dan memiliki aktivitas cukup padat seperti wilayah perkantoran dan pendidikan. Oleh sebab itu, pemerintah menerapkan sistem pengurangan aktivitas di luar rumah untuk mengurangi penyebaran virus Corona.

Salah satu pencegahan untuk mengurangi risiko tertular virus Corona adalah dengan mengkonsumsi makanan yang berkualitas. Kebutuhan pangan berkualitas ini terus meningkat. Masyarakat juga dituntut untuk semakin selektif dalam memilih tempat untuk berbelanja. Protokol kesehatan dituntut untuk selalu dilaksanakan agar tidak menambah banyak korban. Tetapi karena banyak pasar tradisional yang ditutup, masyarakat merasa kesulitan untuk mendapatkan bahan pangan yang berkualitas. Masyarakat yang biasanya berbelanja langsung keluar dan memilih sendiri produk yang akan dibelinya ini khawatir jika harus membeli produk secara daring.
Kemajuan teknologi yang pesat menyebabkan akses informasi untuk memperoleh produk makanan sehat maupun organik saat ini bukan lagi menjadi hal yang rumit. Penjual dan pembeli dapat berinteraksi langsung melalui dunia maya tanpa harus pergi keluar rumah. Melalui toko online, penjual dapat menawarkan produkproduk pilihan dan konsumen bebas memilih produk yang mereka kehendaki. Peluang untuk memasarkan produk dilakukan melalui toko online yang berbasis pada aplikasi (android/iOS) maupun toko online yang menjual sayuran pada marketplace seperti di Bukalapak maupun Tokopedia. Contoh $e$ commerce dan marketplace yang menjual sayur dan buah terlihat pada Tabel 1 .

Tabel 1. Sebagian aplikasi dan situs beli sayur dan buah secara online

\begin{tabular}{ll}
\hline \multicolumn{1}{c}{ Nama } & \multicolumn{1}{c}{ Keterangan } \\
\hline Sayurbox & $\begin{array}{l}\text { Menggunakan website serta } \\
\text { aplikasi Android dan iOS }\end{array}$ \\
RegoPantes & $\begin{array}{l}\text { Menggunakan website dan } \\
\text { aplikasi Android }\end{array}$ \\
Kecipir.com & $\begin{array}{l}\text { Menggunakan website serta } \\
\text { aplikasi Android dan iOS }\end{array}$ \\
Limakilo & $\begin{array}{l}\text { Menggunakan aplikasi } \\
\text { Android }\end{array}$ \\
TaniHub & $\begin{array}{l}\text { Tersedia di Android dan iOS } \\
\text { Tersedia di aplikasi Android, }\end{array}$ \\
Tukangsayur.co & $\begin{array}{l}\text { hanya untuk wilayah } \\
\text { Jabotabek }\end{array}$ \\
Etanee & $\begin{array}{l}\text { Tersedia di Android dan iOS } \\
\text { Beberapa menjual sayuran } \\
\text { secara online melalui } \\
\text { Bukalapak, } \\
\text { Tokopedia }\end{array}$ \\
\hline marketplace ini
\end{tabular}

Banyaknya pilihan e-commerce dan marketplace ini membuat persaingan 
antar ritel semakin ketat. Terlebih lagi di masa pandemi banyak sekali konsumen yang dipaksa untuk meninggalkan ritel tradisionalnya dan beralih ke $e$ commerce. E-commerce yang tidak mampu untuk memenuhi permintaan konsumennya dengan baik tentu akan kalah dengan e-commerce lain.

XYZ merupakan salah satu $e$ commerce yang menjual sayur dan buah yang sudah berdiri sebelum pandemi. XYZ mampu bertahan dalam persaingan yang ketat saat pandemi terjadi. Hal ini adalah hasil dari kemampuan XYZ yang mampu memenuhi permintaan konsumennya dengan baik. Tidak hanya itu, XYZ juga memberikan pelayanan yang baik kepada konsumennya.

Ketatnya persaingan di tengah pandemi menuntut XYZ untuk terus melakukan peningkatan dalam kualitas pelayanan dan kualitas produknya. Peningkatan ini bertujuan untuk memuaskan serta menjaga konsumen yang sudah sangat banyak dan mengalami peningkatan berlipat sejak adanya pandemi.

Saat ini XYZ sedang menghadapi tantangan pada pemasarannya. Tantangan yang sedang dihadapi ini berkaitan dengan kepuasan konsumen. Kepuasan konsumen merupakan sebuah perasaan suka atau tidak suka yang dirasakan konsumen terhadap suatu produk atau jasa akibat dari adanya perbandingan antara harapan saat sebelum membeli produk atau jasa dengan kinerja yang diberikan oleh suatu perusahaan setelah adanya transaksi pembelian. Kepuasan konsumen menjadi sebuah kunci bagi kesuksesan perusahaan. Hal ini yang harusnya dijadikan sebagai fokus utama suatu perusahaan.

XYZ merupakan e-commerce yang sudah berdiri cukup lama yaitu sejak tahun 2016. Keberadaan XYZ yang terbilang cukup lama membuat XYZ menjadi salah satu e-commerce terkenal. Masih ada hal-hal yang perlu ditingkatkan kembali oleh XYZ agar dapat mencapai sebuah kepuasan bagi konsumen. Kepuasan konsumen tersebut dapat ditingkatkan dengan cara memberikan pelayanan yang lebih baik seperti menanggapi keluhan konsumen dengan segera, membantu konsumen memecahkan masalah dengan cepat, dan selalu menjaga kualitas produk dan jasa yang ditawarkan. Selain itu, berinteraksi dengan konsumen melalui media sosial juga penting untuk meningkatkan kepuasan konsumen dan adanya kedekatan antara perusahaan dengan konsumennya juga dapat membuat 
kepuasan yang telah didapatkan tersebut terjaga. Kepuasan konsumen sangat penting untuk dicapai karena apabila konsumen tidak puas akan berakibat pada word of mouth yang negatif yang timbul dari konsumen. Word of mouth berperan penting karena dapat memberikan referensi atau pengalaman yang yang dirasakan konsumen saat berbelanja kepada calon konsumen lainnya. Oleh karena itu, kepuasan konsumen perlu dijaga karena apabila konsumen merasa puas, mereka tidak akan ragu untuk berbagi pengalaman yang telah dialami.

Tingkat kepuasan yang didapatkan oleh konsumen XYZ akan mempengaruhi tingkat loyalitas konsumen pada XYZ. Konsumen yang puas terhadap kinerja yang diberikan oleh suatu perusahaan biasanya akan menjadi konsumen yang loyal juga. Oleh karena itu dilakukan penelitian untuk mengukur tingkat kepuasan dan tingkat loyalitas konsumen XYZ di Jabodetabek. Pemilihan lokasi Jabodetabek dilakukan karena XYZ pertama kali menjual produknya di area Jabodetabek. Selain itu, karena sudah lama menjadi e-commerce yang menyediakan sayur dan buah di Jabodetabek, XYZ memiliki lebih banyak konsumen dibandingkan daerah lainnya.
Pada penelitian ini, kualitas produk dan kualitas layanan digunakan untuk mengukur kepuasan konsumen. Hal ini dilakukan karena kualitas produk dan layanan merupakan alat yang dapat mengukur kepuasan kepada konsumen tersebut.

\section{METODE PENELITIAN}

Objek penelitian ini adalah tingkat kepuasan dan loyalitas konsumen XYZ di Jabodetabek. Penelitian ini dilakukan secara online dengan menggunakan fitur direct message di Instagram untuk menyebarkan kuesioner pada pelanggan XYZ. XYZ dipilih karena memiliki banyak pengikut di media sosial.

Penelitian ini menggunakan desain kuantitatif dengan Teknik explanatory survey. Data yang digunakan adalah data primer berasal dari hasil pengisian kuesioner oleh responden. Selain itu penelitian ini juga menggunakan data sekunder yang berasal dari jurnal dan media informasi lainnya yang berkaitan dengan penelitian ini.

Populasi pada penelitian ini adalah seluruh konsumen XYZ. Metode pengambilan sampel yang digunakan adalah metode convenience sampling. Sampel penelitian ini adalah konsumen yang pernah berbelanja sayur dan buah di 
XYZ dan berdomisili di Jabodetabek. Estimasi sampel yang digunakan pada penelitian ini menggunakan rumus Slovin. Tingkat keyakinan pada penarikan sampel sebesar 95\% sehingga jumlah sampel yang dibutuhkan adalah 96.

Analisis yang digunakan pada penelitian ini adalah analisis karakteristik konsumen, Customer Satisfaction Index, dan Importance Performance Analysis. Analisis karakteristik konsumen, dan tingkat loyalitas konsumen menggunakan analisis deskriptif. Analisis deskriptif karakteristik konsumen menggambarkan tentang jenis kelamin konsumen, usia konsumen, tempat tinggal konsumen, pendidikan terakhir konsumen, pekerjaan konsumen, dan pengeluaran rata-rata konsumen. Analisis deskriptif karakteristik konsumen juga menggambarkan awal mula konsumen berbelanja di XYZ, peningkatan frekuensi belanja online kebutuhan pangan akibat pandemi, frekuensi berbelanja di XYZ selama andemi, dan kesediaan untuk berbelanja di XYZ saat pandemi berakhir. Analisis deskriptif tingkat loyalitas konsumen menggambarkan kesediaan konsumen untuk melakukan pembelian ulang, konsumen yang tidak mudah terpengaruh oleh produk barang atau jasa lain, kesediaan konsumen untuk merekomendasikan kepada orang lain, dan kesediaan konsumen untuk membeli diluar lini produk atau jasa. Analisis tingkat kepuasan konsumen menggunakan Customer Satisfaction Index dan Importance Performance Analysis. Analisis kepuasan konsumen mengukur kualitas layanan dan kualitas produk yang ditawarkan XYZ.

\section{HASIL DAN PEMBAHASAN}

\section{Karakteristik Konsumen}

1) Jenis kelamin

Tabel 2. Karakteristik Konsumen Menurut Jenis

\begin{tabular}{ccc}
\multicolumn{1}{c}{ Kelamin } & \\
$\begin{array}{c}\text { Jenis } \\
\text { Kelamin }\end{array}$ & $\begin{array}{c}\text { Jumlah } \\
\text { Responden }\end{array}$ & Persentase \\
\hline Laki-laki & 17 & $17 \%$ \\
Perempuan & 83 & $83 \%$ \\
\hline \multicolumn{1}{c}{ Total } & $\mathbf{1 0 0}$ & $\mathbf{1 0 0 \%}$ \\
\hline
\end{tabular}

Berdasarkan Tabel 2 mayoritas konsumen XYZ berjenis kelamin perempuan. Hal ini menunjukkan bahwa perempuan memegang kendali terhadap tugas rumah tangga.

\section{2) Usia}

Tabel 3. Karakteristik Konsumen Menurut Usia

\begin{tabular}{lcc}
\hline \multicolumn{1}{c}{ Usia } & $\begin{array}{c}\text { Jumlah } \\
\text { Responden }\end{array}$ & Persentase \\
\hline Gen. alpha & 0 & $0 \%$ \\
Gen. Z & 84 & $84 \%$ \\
Gen. Y & 16 & $16 \%$ \\
Gen. X & 0 & $0 \%$ \\
Baby Boomers & 0 & $0 \%$ \\
\hline \multicolumn{1}{c}{ Total } & $\mathbf{1 0 0}$ & $\mathbf{1 0 0 \%}$ \\
\hline
\end{tabular}


Berdasarkan Tabel 3 mayoritas konsumen $\mathrm{XYZ}$ berasal dari generasi $\mathrm{Z}$ yaitu berusia 10 sampai 30 tahun. Usia ini termasuk dalam generasi Z. Generasi Z biasa disebut generasi Google. Generasi ini menunjukkan bahwa penggunaan media online adalah sebagai perangkat yang selalu berada di dalam genggaman. Hal ini menjadikan seluruh konsumen XYZ merupakan generasi yang selalu menggunakan internet.

3) Tempat tinggal

Tabel 4. Karakteristik Konsumen Menurut Tempat Tinggal

\begin{tabular}{lcc}
\hline $\begin{array}{c}\text { Tempat } \\
\text { Tinggal }\end{array}$ & $\begin{array}{c}\text { Jumlah } \\
\text { Responden }\end{array}$ & Persentase \\
\hline Jakarta & 49 & $49 \%$ \\
Bogor & 13 & $13 \%$ \\
Depok & 11 & $11 \%$ \\
Tangerang & 11 & $11 \%$ \\
Bekasi & 16 & $16 \%$ \\
\hline \multicolumn{1}{c}{ Total } & $\mathbf{1 0 0}$ & $\mathbf{1 0 0 \%}$ \\
\hline
\end{tabular}

Berdasarkan Tabel 4, mayoritas konsumen XYZ berasal dari Jakarta. Hal ini sesuai dengan letak gudang pengantaran barang yang berada di Jakarta. Hal ini menunjukkan bahwa konsumen XYZ mayoritas berasal dari Jakarta dan sesuai dengan letak gudang pengantaran barang yang berada di Jakarta. Selain itu, Bekasi dan Bogor merupakan domisili konsumen XYZ terbanyak yang berada di tingkat kedua dan ketiga. Tidak ada alasan khusus yang mempengaruhi letak tempat tinggal dan jarak pengiriman dari XYZ karena mayoritas konsumen memaksimalkan jumlah belanja mereka agar dapat menggunakan fitur gratis ongkir yang diberikan.

4) Pendidikan terakhir

Tabel 5. Karakteristik Konsumen Menurut Pendidikan Terakhir

\begin{tabular}{lcc}
\hline $\begin{array}{c}\text { Pendidikan } \\
\text { Terakhir }\end{array}$ & $\begin{array}{c}\text { Jumlah } \\
\text { Responden }\end{array}$ & Persentase \\
\hline SMP & 0 & $0 \%$ \\
SMA & 25 & $25 \%$ \\
Diploma & 15 & $15 \%$ \\
$(1 / 2 / 3 / 4)$ & & \\
Strata $(1 / 2 / 3)$ & 60 & $60 \%$ \\
\hline \multicolumn{1}{c}{ Total } & $\mathbf{1 0 0}$ & $\mathbf{1 0 0 \%}$ \\
\hline
\end{tabular}

Berdasarkan Tabel 5 diketahui bahwa konsumen XYZ kebanyakan sudah berada di pendidikan berjenjang Strata. Hal ini disebabkan karena perusahaan XYZ menargetkan perusahaannya pada masyarakat yang sudah bekerja.

5) Pekerjaan

Tabel 6. Karakteristik Konsumen Menurut Pekerjaan

\begin{tabular}{lcc}
\hline \multicolumn{1}{c}{ Pekerjaan } & $\begin{array}{c}\text { Jumlah } \\
\text { Responden }\end{array}$ & Persentase \\
\hline Pelajar & 2 & $2 \%$ \\
Mahasiswa & 29 & $29 \%$ \\
Pegawai & 7 & $7 \%$ \\
Negeri/BUMN & 38 & $38 \%$ \\
Pegawai Swasta & 12 & $12 \%$ \\
Wiraswasta/Pengusaha & 12 & $12 \%$ \\
Lainnya & $\mathbf{1 0 0}$ & $\mathbf{1 0 0 \%}$ \\
\hline \multicolumn{1}{c}{ Total } &
\end{tabular}

Berdasarkan Tabel 6 mayoritas konsumen yang berbelanja di XYZ berprofesi sebagai pegawai swasta. Namun terdapat konsumen yang bekerja di bidang lainnya seperti sebagai ibu 
rumah tangga, guru, dan bekerja di bagian lain maupun tidak bekerja (menganggur) serta masih menuntut ilmu. Konsumen yang masih menuntut ilmu yaitu pelajar dan mahasiswa. Mahasiswa menjadi konsumen terbanyak kedua setelah pegawai swasta. Mahasiswa yang berbelanja di XYZ ini kebanyakan hanya membantu orang tuanya untuk berbelanja online. Hal ini merupakan bentuk bantuan dan kerjasama agar konsumen mahasiswa dan orang tuanya tidak perlu berbelanja keluar rumah saat sedang pandemi sehingga membuat banyak konsumen XYZ masih berstatus mahasiswa. Selain itu terdapat mahasiswa yang berbelanja di XYZ untuk memenuhi kebutuhan bahan pangannya karena tinggal di kos.

6) Pengeluaran rata-rata perbulan

Tabel 7. Karakteristik Konsumen Menurut Pengeluaran Rata-rata Perbulan

\begin{tabular}{lcc}
\hline Pengeluaran (Rp) & $\begin{array}{c}\text { Jumlah } \\
\text { Responden }\end{array}$ & $\begin{array}{c}\text { Persen- } \\
\text { tase }\end{array}$ \\
\hline$\leq 00.000$ & 8 & $8 \%$ \\
$700.000-1.000 .000$ & 13 & $13 \%$ \\
$1.000 .000-\mathrm{Rp} 2.000 .000$ & 18 & $18 \%$ \\
$2.000 .000-\mathrm{Rp} 3.000 .000$ & 19 & $19 \%$ \\
$\geq 3.000 .000$ & 42 & $42 \%$ \\
\hline \multicolumn{1}{c}{ Total } & $\mathbf{1 0 0}$ & $\mathbf{1 0 0 \%}$ \\
\hline
\end{tabular}

Berdasarkan Tabel 7 mayoritas konsumen $\mathrm{XYZ}$ memiliki pengeluaran rata-rata perbulan lebih dari $\mathrm{Rp} 3000.000$. Hal ini sesuai dengan penelitian Engel et al (2010) bahwa semakin besar tingkat pendapatan seseorang maka akan semakin besar daya beli seseorang tersebut terhadap suatu barang dan jasa yang ditawarkan oleh suatu produsen. Hal ini menyebabkan semakin besar juga pengeluaran seseorang.

\section{7) Awal mula berbelanja}

Tabel 8. Karakteristik Konsumen Menurut Awal Mula Berbelanja

\begin{tabular}{lcc}
\hline \multicolumn{1}{c}{$\begin{array}{c}\text { Awal Mula } \\
\text { Berbelanja }\end{array}$} & $\begin{array}{c}\text { Jumlah } \\
\text { Responden }\end{array}$ & Persentase \\
\hline $\begin{array}{l}\text { Sebelum terjadi } \\
\text { pandemi }\end{array}$ & 43 & $43 \%$ \\
Saat terjadi pandemi & 57 & $57 \%$ \\
\hline \multicolumn{1}{c}{ Total } & $\mathbf{1 0 0}$ & $\mathbf{1 0 0 \%}$ \\
\hline
\end{tabular}

Berdasarkan Tabel 8 mayoritas konsumen XYZ pertama kali berbelanja di XYZ saat terjadi pandemi. Adanya peningkatan konsumen ini disebabkan karena toko online yang menjual bahan pangan seperti XYZ sangat memudahkan terlebih di masa pandemi. Layanan yang diberikan e-commerce sangat memberikan kemudahan karena tidak perlu berbelanja keluar rumah saat sedang diterapkan protokol kesehatan seperti physical distancing. XYZ membantu konsumennya mengurangi mobilisasi untuk mendistribusikan pangan. Selain itu, harga yang ditawarkan juga tidak terpaut jauh dengan berbelanja di langsung ke toko dan produk yang ditawarkan juga merupakan kualitas yang baik walaupun konsumen turun langsung untuk memilih sendiri. 
8) Peningkatan frekuensi belanja online kebutuhan pangan akibat pandemi

\begin{tabular}{ccc} 
Tabel 9. $\begin{array}{c}\text { Karakteristik } \\
\text { Peningkatan } \\
\text { Online Kebutuhan Pangan } \\
\text { Pandemi }\end{array}$ & $\begin{array}{c}\text { Konsumen } \\
\text { Frekuensi }\end{array}$ & $\begin{array}{c}\text { Menurut } \\
\text { Belanja } \\
\text { Akibat }\end{array}$ \\
\hline $\begin{array}{c}\text { Terjadi Peningkatan } \\
\text { Frekuensi Belanja } \\
\text { Online Kebutuhan } \\
\text { Pangan Akibat } \\
\text { Pandemi }\end{array}$ & $\begin{array}{c}\text { Jumlah } \\
\text { Responden }\end{array}$ & $\begin{array}{c}\text { Persen- } \\
\text { tase }\end{array}$ \\
\hline Ya & 87 & $87 \%$ \\
Tidak & 13 & $13 \%$ \\
\hline Total & $\mathbf{1 0 0}$ & $\mathbf{1 0 0 \%}$ \\
\hline
\end{tabular}

Berdasarkan Tabel 9 mayoritas konsumen XYZ setuju bahwa terjadi adanya peningkatan frekuensi belanja online untuk memenuhi kebutuhan pangan akibat pandemi. Terjadinya peningkatan ini sesuai dengan peraturan yang menyatakan untuk menghindari kerumunan dan untuk selalu berada di rumah. Hal ini yang menyebabkan adanya peningkatan frekuensi belanja online kebutuhan pangan.

9) Frekuensi berbelanja selama pandemi

\begin{tabular}{|c|c|c|c|c|}
\hline Tabel & 10. & $\begin{array}{l}\text { Karakteristik } \\
\text { Frekuensi } \\
\text { Pandemi (Sej }\end{array}$ & $\begin{array}{c}\text { Konsumen } \\
\text { Berbelanja } \\
\text { ak Maret } 202\end{array}$ & $\begin{array}{l}\text { Menurut } \\
\text { Selama }\end{array}$ \\
\hline \multicolumn{3}{|c|}{$\begin{array}{l}\text { Frekuensi Berbelanja } \\
\text { Selama Pandemi } \\
\text { (Sejak Maret 2020) }\end{array}$} & $\begin{array}{c}\text { Jumlah } \\
\text { Responden }\end{array}$ & $\begin{array}{l}\text { Persen- } \\
\text { tase }\end{array}$ \\
\hline \multicolumn{3}{|c|}{$1-3$ kali } & 50 & $50 \%$ \\
\hline \multicolumn{3}{|c|}{$4-6$ kali } & 24 & $24 \%$ \\
\hline \multicolumn{3}{|c|}{$7-9$ kali } & 11 & $11 \%$ \\
\hline \multicolumn{3}{|c|}{$\geq 10$ kali } & 15 & $15 \%$ \\
\hline \multicolumn{3}{|c|}{ Total } & 100 & $100 \%$ \\
\hline
\end{tabular}

Berdasarkan Tabel 10 mayoritas konsumen XYZ telah berbelanja 1 sampai 3 kali sejak Maret 2020. Hal ini mengindikasikan bahwa mayoritas konsumen tidak memilih XYZ sebagai pemenuh kebutuhan pangan utama karena selama 9 bulan pandemi mereka tidak rutin berbelanja satu bulan sekali untuk memenuhi kebutuhan pangannya dari XYZ. Konsumen yang tidak memilih XYZ sebagai pemenuh kebutuhan pangan selama pandemi tersebut umumnya memiliki pasar yang berada dekat dari rumahnya sehingga tetap memilih belanja ke pasar, mengandalkan tukang sayur keliling yang tetap berjualan selama pandemi, maupun menggunakan sarana lain seperti bantuan dari kelompok ibuibu komplek yang mengadakan jasa titip barang belanjaan untuk membantu warga komplek lainnya yang tidak sempat untuk ke pasar.

10) Kesediaan untuk tetap berbelanja saat pandemi berakhir

Tabel 11. Karakteristik Konsumen Menurut Kesediaan Untuk Tetap Berbelanja Saat Pandemi Berakhir

\begin{tabular}{ccc}
\hline $\begin{array}{c}\text { Kesediaan Untuk } \\
\text { Tetap Berbelanja } \\
\text { Saat Pandemi } \\
\text { Berakhir }\end{array}$ & $\begin{array}{c}\text { Jumlah } \\
\text { Responden }\end{array}$ & $\begin{array}{c}\text { Persen- } \\
\text { tase }\end{array}$ \\
\hline Ya & 87 & $87 \%$ \\
Tidak & 13 & $13 \%$ \\
\hline Total & $\mathbf{1 0 0}$ & $\mathbf{1 0 0 \%}$ \\
\hline
\end{tabular}

Berdasarkan Tabel 11 mayoritas konsumen bersedia untuk tetap berbelanja di XYZ apabila pandemi berakhir walaupun terdapat beberapa konsumen yang tidak bersedia untuk 
tetap berbelanja di XYZ apabila pandemi berakhir. Konsumen yang tidak bersedia untuk berbelanja di XYZ saat pandemi berakhir ini memperlihatkan adanya faktor yang menunjukkan bahwa adanya ketidakpuasan yang dirasakan oleh konsumen. Faktor ketidakpuasan tersebut salah satunya adalah konsumen merasa bahwa kualitas sayur atau buah yang berada di XYZ sama seperti yang ditawarkan di ritel offline. Namun konsumen tersebut lebih suka berbelanja offline karena dapat memilih sendiri produk yang diinginkan.

\section{Uji Validitas dan Reliabilitas}

1) Uji Validitas

Berdasarkan uji validitas yang dilakukan pada 13 responden konsumen XYZ diluar responden penelitian didapatkan bahwa $r_{\text {hitung }}$ seluruh item kuesioner lebih besar dari $r_{\text {tabel. }} \cdot R_{\text {tabel }}$ untuk 13 responden adalah 0,553 sedangkan $r_{\text {tabel }}$ pada setiap item kuesioner adalah lebih besar dari $\mathrm{r}_{\text {tabel }}=$ 0,553. Maka dapat disimpulkan bahwa instrumen penelitian yang digunakan valid dan dapat digunakan sebagai instrumen penelitian.

2) Uji Reliabilitas

Berdasarkan uji reliabilitas yang dilakukan pada 13 responden konsumen
XYZ diluar responden penelitian didapatkan bahwa nilai alpha Cronbach $0,9875>0,6$. Maka dapat disimpulkan bahwa instrumen penelitian yang digunakan reliabel untuk dijadikan instrumen penelitian.

\section{Tingkat Kepuasan Konsumen}

1) Customer Satisfaction Index

Tingkat kepuasan konsumen dihitung dengan menggunakan Customer Satisfaction Index (CSI). Hasil perhitungan Customer Satisfaction Index (CSI) dapat dilihat melalui Tabel 12.

Berdasarkan Tabel 12, hasil tingkat kepuasan konsumen XYZ adalah 0,898. Nilai tersebut masuk ke dalam kriteria Sangat Puas. Hal ini mengidentifikasikan bahwa umumnya konsumen yang berbelanja di XYZ merasa sangat puas walaupun terdapat 0,102 kepuasan yang belum tercapai. Cara yang dapat dilakukan untuk meningkatkan persentase kepuasan konsumen di XYZ adalah dengan melakukan peningkatan kinerja yang ada. Untuk mengetahui prioritas-prioritas atribut tersebut dapat dilihat melalui hasil diagram kartesius Importance Performance Analysis. 
Tabel 12. Perhitungan Customer Satisfaction Index di XYZ

\begin{tabular}{|c|c|c|c|c|c|}
\hline \multirow[b]{2}{*}{ No } & \multirow[b]{2}{*}{ Atribut } & \multicolumn{2}{|c|}{ Tingkat Kepentingan } & \multicolumn{2}{|c|}{ Tingkat Kinerja } \\
\hline & & $\begin{array}{c}\text { Mean } \\
\text { Importance } \\
\text { Score } \\
\end{array}$ & $\begin{array}{l}\text { Weight } \\
\text { Factor }\end{array}$ & $\begin{array}{c}\text { Mean } \\
\text { Performance } \\
\text { Score }\end{array}$ & $\begin{array}{l}\text { Weight } \\
\text { Score }\end{array}$ \\
\hline 1 & Desain aplikasi menarik & 4,55 & 0,038 & 4,6 & 0,174 \\
\hline 2 & Desain media sosial menarik & 4,3 & 0,036 & 4,51 & 0,162 \\
\hline 3 & Desain pengetahuan tentang produk menarik & 4,64 & 0,039 & 4,44 & 0,172 \\
\hline 4 & Promosi yang dilakukan menarik & 4,59 & 0,038 & 4,42 & 0,169 \\
\hline 5 & Karyawan melayani dengan tepat & 4,69 & 0,039 & 4,49 & 0,175 \\
\hline 6 & $\begin{array}{l}\text { Harga yang dibayarkan sesuai dengan } \\
\text { kualitas yang didapatkan }\end{array}$ & 4,7 & 0,039 & 4,43 & 0,174 \\
\hline 7 & $\begin{array}{l}\text { Produk yang dikirimkan sesuai dengan } \\
\text { pesanan }\end{array}$ & 4,75 & 0,040 & 4,49 & 0,178 \\
\hline 8 & Karyawan melayani dengan cepat & 4,55 & 0,038 & 4,42 & 0,168 \\
\hline 9 & Waktu pengiriman pesanan cepat & 4,7 & 0,039 & 4,52 & 0,177 \\
\hline 10 & $\begin{array}{l}\text { Karyawan membantu konsumen yang } \\
\text { kesulitan dalam melakukan pemesanan }\end{array}$ & 4,55 & 0,038 & 4,37 & 0,166 \\
\hline 11 & $\begin{array}{l}\text { Karyawan menguasai pengetahuan tentang } \\
\text { produk yang dijual }\end{array}$ & 4,57 & 0,038 & 4,3 & 0,164 \\
\hline 12 & Karyawan selalu bersikap sopan dan ramah & 4,73 & 0,039 & 4,56 & 0,180 \\
\hline 13 & $\begin{array}{l}\text { Konsumen merasa aman dan percaya saat } \\
\text { melakukan transaksi }\end{array}$ & 4,78 & 0,040 & 4,67 & 0,186 \\
\hline 14 & $\begin{array}{l}\text { Karyawan mau mendengarkan keluhan } \\
\text { konsumen }\end{array}$ & 4,62 & 0,039 & 4,44 & 0,171 \\
\hline 15 & $\begin{array}{l}\text { Karyawan menanggapi keluhan konsumen } \\
\text { dengan baik }\end{array}$ & 4,67 & 0,039 & 4,5 & 0,175 \\
\hline 16 & Sayur dan buah berwarna cerah & 4,6 & 0,038 & 4,55 & 0,174 \\
\hline 17 & Sayur dan buah tidak pucat & 4,6 & 0,038 & 4,57 & 0,175 \\
\hline 18 & Bentuk sayur dan buah tidak cacat atau rusak & 4,64 & 0,039 & 4,54 & 0,176 \\
\hline 19 & Ukuran sayur dan buah normal & 4,5 & 0,038 & 4,57 & 0,171 \\
\hline 20 & Sayur dan buah tidak dalam keadaan layu & 4,79 & 0,040 & 4,54 & 0,181 \\
\hline 21 & $\begin{array}{l}\text { Bentuk sayur dan buah sesuai dengan yang } \\
\text { ditawarkan }\end{array}$ & 4,73 & 0,039 & 4,57 & 0,180 \\
\hline 22 & Ukuran sayur dan buah seragam & 4,05 & 0,034 & 4,3 & 0,145 \\
\hline 23 & $\begin{array}{l}\text { Rasa sayur atau buah sesuai dengan yang } \\
\text { ditawarkan }\end{array}$ & 4,67 & 0,039 & 4,48 & 0,174 \\
\hline 24 & Rasa sayur dan buah enak & 4,7 & 0,039 & 4,55 & 0,178 \\
\hline 25 & $\begin{array}{l}\text { Tekstur sayur dan buah sesuai dengan yang } \\
\text { ditawarkan }\end{array}$ & 4,73 & 0,039 & 4,57 & 0,180 \\
\hline 26 & $\begin{array}{l}\text { Tekstur sayur dan buah tidak keras atau tidak } \\
\text { lembek }\end{array}$ & 4,6 & 0,038 & 4,36 & 0,167 \\
\hline & $\begin{array}{lc} & \text { Total } \\
\end{array}$ & & & & 4,492 \\
\hline & Customer Satisfacti & n Index & & & 0.898 \\
\hline
\end{tabular}

2) Importance Performance Analysis

Importance Performance Analysis

(IPA) digunakan untuk menganalisis kuadran untuk menjelaskan kepentingan dan kepuasan konsumen melalui atribut yang berhubungan dengan kualitas layanan dan kualitas produk yang mempengaruhi konsumennya. Atributatribut yang digunakan masing-masing mempunyai pengaruh terhadap tingkat kepuasan konsumen. Agar XYZ dapat memenuhi tingkat kepuasan konsumen, XYZ perlu mempertahankan dan memperbaiki tingkat kinerja dari setiap 
atributnya. Berikut adalah hasil analisis tingkat kepentingan konsumen dan tingkat kinerja XYZ:

Berdasarkan Tabel 13, nilai ratarata tingkat kinerja XYZ lebih kecil dibandingkan nilai rata-rata tingkat kepentingan. Hal ini berarti pelanggan sangat puas dengan kinerja yang diberikan XYZ. Namun, mayoritas tingkat kesesuaian pada XYZ bernilai kurang dari 1. Hal ini mengindikasikan bahwa kualitas layanan yang diberikan kurang memenuhi atau kurang dianggap penting oleh konsumen. Nilai rata-rata tingkat kinerja dan tingkat kepentingan berfungsi sebagai garis tengah $\mathrm{X}$ dan $\mathrm{Y}$ pada diagram kartesius Importance Performance Analysis (IPA). Nilai tersebut kemudian digunakan untuk menyebarkan atribut-atribut pada diagram kartesius sesuai tingkat kinerjanya yaitu sebagai berikut:

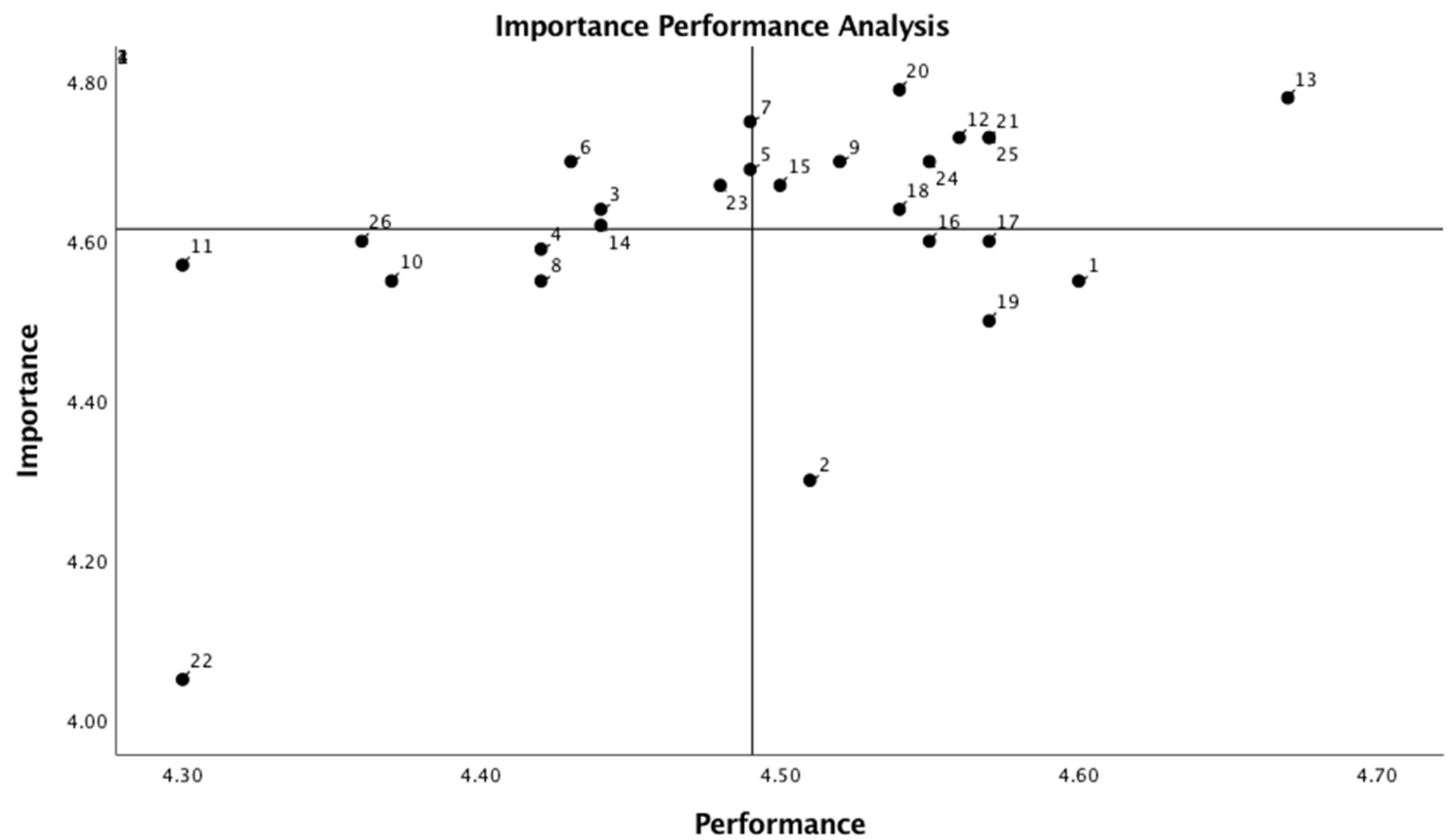

Gambar 1. Importance Performance Analysis

Keterangan:

1. Desain aplikasi menarik

2. Desain media sosial menarik

3. Desain pengetahuan tentang produk menarik

4. Promosi yang dilakukan menarik

5. Karyawan melayani dengan tepat
14. Karyawan mau mendengarkan keluhan konsumen

15. Karyawan menanggapi keluhan konsumen dengan baik

16. Sayur dan buah berwarna cerah

17. Sayur dan buah tidak pucat

18. Bentuk sayur dan buah tidak cacat atau rusak 
6. Harga yang dibayarkan sesuai dengan kualitas yang didapatkan

7. Produk yang dikirimkan sesuai dengan pesanan

8. Karyawan melayani dengan cepat

9. Waktu pengiriman pesanan cepat

10. Karyawan membantu konsumen yang kesulitan dalam melakukan pemesanan

11. Karyawan menguasai pengetahuan tentang produk yang dijual

12. Karyawan selalu bersikap sopan dan ramah

13. Konsumen merasa aman dan percaya saat melakukan transaksi

Pada diagram kartesius IPA, setiap kuadran menjelaskan posisinya masingmasing yang mempengaruhi kepuasan konsumen. Masing-masing kuadran menjelaskan rata-rata nilai kepentingan dan tingkat kinerja. Berikut merupakan interpretasi dari setiap kuadran IPA pada XYZ:

Kuadran I (Prioritas Utama)

Kuadran I adalah kuadran yang mengandung atribut-atribut yang dianggap penting oleh konsumen. Namun, atribut-atribut dalam kuadran ini belum sesuai dengan harapan konsumen. Hal tersebut dapat dilihat dari tingkat kinerjanya yang masih rendah. Atributatribut yang terletak pada kuadran I yaitu desain pengetahuan tentang produk menarik, karyawan melayani dengan tepat, harga yang dibayarkan sesuai dengan kualitas yang didapatkan, produk
19. Ukuran sayur dan buah normal

20. Sayur dan buah tidak dalam keadaan layu

21. Bentuk sayur dan buah sesuai dengan yang ditawarkan

22. Ukuran sayur dan buah seragam

23. Rasa sayur atau buah sesuai dengan yang ditawarkan

24. Rasa sayur dan buah enak

25. Tekstur sayur dan buah sesuai dengan yang ditawarkan

26. Tekstur sayur dan buah tidak keras atau tidak lembek

yang dikirimkan sesuai dengan pesanan, karyawan mau mendengarkan keluhan konsumen, dan rasa sayur atau buah sesuai dengan yang ditawarkan.

Kuadran II (Pertahankan Prestasi)

Kuadran II adalah kuadran yang mengandung atribut-atribut yang dianggap penting oleh konsumen. Pada kuadran II atribut yang ada sudah dirasakan oleh konsumen. Hal tersebut dilihat dari tingkat kinerjanya yang cukup tinggi. Atribut-atribut yang terletak pada kuadran II yaitu waktu pengiriman pesanan cepat, karyawan selalu bersikap sopan dan ramah, konsumen merasa aman dan percaya saat melakukan transaksi, karyawan menanggapi keluhan konsumen dengan baik, bentuk sayur dan buah tidak cacat atau rusak, sayur dan buah tidak dalam keadaan layu, bentuk sayur dan buah sesuai dengan yang 
ditawarkan, rasa sayur dan buah enak, dan tekstur sayur dan buah sesuai dengan yang ditawarkan.

Kuadran III (Prioritas Rendah)

Kuadran III adalah kuadran yang mengandung atribut-atribut yang dirasa kurang penting bagi konsumen. Atributatribut pada kuadran ini dirasa belum dibutuhkan dan memiliki tingkat kinerja yang kurang baik. Atribut-atribut yang terletak pada kuadran III yaitu promosi yang dilakukan menarik, karyawan melayani dengan cepat, karyawan membantu konsumen yang kesulitan dalam melakukan pemesanan, karyawan menguasai pengetahuan tentang produk yang dijual, ukuran sayur dan buah seragam, dan tekstur sayur dan buah tidak keras dan tidak lembek.

Kuadran IV (Berlebihan)

Kuadran IV adalah kuadran yang atribut-atributnya dianggap kurang penting bagi konsumen. Atribut pada kuadran ini juga dianggap berlebihan dalam memberikan kepuasan konsumen dan dirasa belum diperlukan oleh konsumen. XYZ tidak perlu memprioritaskan atribut yang terletak pada kuadran ini karena kinerja yang diberikan dirasa berlebihan dan dapat dialokasikan untuk memperbaiki atributatribut pada kuadran I. Atribut-atribut yang terletak pada kuadran IV yaitu desain aplikasi menarik, desain media social menarik, sayur dan buah berwarna cerah, sayur dan buah tidak pucat, dan ukuran sayur dan buah normal.

\section{Tingkat Loyalitas Konsumen}

Loyalitas konsumen merupakan kesetiaan konsumen pada suatu perusahaan, merek, ataupun produk (Rangkuti, 2002). Loyalitas konsumen didapatkan dari kepuasan konsumen yang kemudian melakukan pembelian ulang terhadap suatu produk untuk dikonsumsi kembali. Pada penelitian ini, tingkat loyalitas konsumen ditentukan menggunakan empat variabel berikut:

1) Melakukan pembelian ulang

Konsumen yang loyal akan melakukan pembelian ulang pada $e$ commerce penjual produk pangan dalam waktu dekat dan melakukan pembelian secara berulang. Indikator yang digunakan pada karakteristik ini adalah dalam waktu dekat dan secara berulang.

Tabel 14.Analisis Tingkat Loyalitas Konsumen Berdasarkan Pembelian Dalam Waktu Dekat

Saya akan kembali membeli produk yang dijual di XYZ dalam waktu dekat

\begin{tabular}{lccc}
\hline Jawaban & Bobot (x) & $\begin{array}{c}\text { Frekuensi } \\
\text { (f) }\end{array}$ & $\begin{array}{c}\text { Skor } \\
\text { (f.x) }\end{array}$ \\
\hline STS & 1 & 1 & 1 \\
TS & 2 & 1 & 2 \\
R & 3 & 19 & 57 \\
S & 4 & 30 & 120 \\
SS & 5 & 49 & 245 \\
\hline \multicolumn{1}{r}{ Total } & & $\mathbf{1 0 0}$ & $\mathbf{4 2 5}$ \\
\hline
\end{tabular}


Berdasarkan Tabel 14 mayoritas konsumen XYZ setuju akan melakukan pembelian ulang dalam waktu dekat. Hal ini berarti mayoritas konsumen XYZ ingin melakukan pembelian ulang dalam waktu dekat.

Tabel 15. Analisis Tingkat Loyalitas Konsumen Berdasarkan Pembelian Ulang

\begin{tabular}{lccc}
\hline \multicolumn{4}{c}{ Saya membeli produk di XYZ secara } \\
berulang
\end{tabular}

Berdasarkan Tabel 15 mayoritas konsumen XYZ setuju bahwa akan melakukan pembelian ulang. Hal ini berarti mayoritas konsumen XYZ akan melakukan pembelian ulang dan menunjukkan loyalitas.

2) Tidak mudah terpengaruh oleh penawaran produk barang atau jasa lain

Konsumen yang loyal cenderung tidak mudah terpengaruh oleh produk atau jasa lain yang ditawarkan pesaing sehingga lebih memilih perusahaan yang sudah memberikan kepuasan baginya. Selain itu konsumen juga merasa bahwa perusahaan tersebut adalah perusahaan yang terbaik. Indikator yang digunakan pada karakteristik ini adalah memilih XYZ dibanding e-commerce lainnya dan merasa XYZ yang terbaik.
Tabel 16. Analisis Tingkat Loyalitas Konsumen Berdasarkan Kekebalan Terhadap Pesaing

\begin{tabular}{lccc}
\hline \multicolumn{4}{c}{ Saya lebih memilih XYZ dibandingkan $\boldsymbol{e}$ - } \\
commerce lainnya \\
Jawaban & $\begin{array}{c}\text { Bobot } \\
(\mathrm{x})\end{array}$ & $\begin{array}{c}\text { Frekuensi } \\
\text { (f) }\end{array}$ & $\begin{array}{c}\text { Skor } \\
\text { (f.x) }\end{array}$ \\
\hline STS & 1 & 0 & 0 \\
TS & 2 & 5 & 10 \\
R & 3 & 15 & 45 \\
S & 4 & 36 & 144 \\
SS & 5 & 44 & 220 \\
\hline \multicolumn{1}{c}{ Total } & & $\mathbf{1 0 0}$ & $\mathbf{4 1 9}$ \\
\hline
\end{tabular}

Berdasarkan Tabel 16 mayoritas konsumen XYZ menyatakan bahwa lebih memilih XYZ dibandingkan dengan $e$ commerce lainnya. Tetapi, terdapat konsumen yang masih ragu serta tidak setuju untuk memilih XYZ dibandingkan e-commerce lainnya. Hal ini berarti masih banyak konsumen yang tertarik dengan e-commerce lain yang serupa.

Tabel 17. Analisis Tingkat Loyalitas Konsumen Berdasarkan Pemilihan E-commerce Terbaik

\begin{tabular}{lccc}
\hline \multicolumn{4}{c}{ Saya merasa XYZ merupakan e-commerce } \\
terbaik
\end{tabular}

Berdasarkan Tabel 17 mayoritas konsumen XYZ menyatakan XYZ merupakan e-commerce terbaik. Tetapi masih terdapat beberapa konsumen yang ragu serta tidak setuju bahwa XYZ merupakan e-commerce terbaik. Hal ini berarti masih banyak konsumen yang 
terpengaruh oleh daya tarik e-commerce lainnya sehingga tidak memilih XYZ sebagai e-commerce terbaik.

3) Merekomendasikan kepada orang lain

Merekomendasikan kepada orang lain salah satunya adalah dengan memberikan testimonial yang berperan penting karena adanya efek word of mouth. Konsumen yang loyal cenderung memberikan testimonial positif. Indikator karakteristik ini adalah mengatakan hal positif mengenai XYZ dan merekomendasikan kepada orang lain.

Tabel 18. Analisis Tingkat Loyalitas Konsumen Berdasarkan Mengatakan Hal Positif

\begin{tabular}{lccc}
\hline \multicolumn{4}{c}{ Saya mengatakan hal positif mengenai XYZ } \\
\hline Jawaban & $\begin{array}{c}\text { Bobot } \\
\text { (x) }\end{array}$ & $\begin{array}{c}\text { Frekuensi } \\
\text { (f) }\end{array}$ & $\begin{array}{c}\text { Skor } \\
\text { (f.x) }\end{array}$ \\
\hline STS & 1 & 0 & 0 \\
TS & 2 & 0 & 0 \\
R & 3 & 7 & 21 \\
S & 4 & 32 & 128 \\
SS & 5 & 61 & 305 \\
\hline \multicolumn{1}{r}{ Total } & & $\mathbf{1 0 0}$ & $\mathbf{4 5 4}$ \\
\hline
\end{tabular}

Berdasarkan Tabel 18 mayoritas konsumen XYZ setuju telah mengatakan hal positif mengenai XYZ dan hanya sedikit konsumen yang ragu untuk mengatakan hal positif mengenai XYZ. Lalu tidak terdapat konsumen yang menyatakan tidak setuju atau sangat tidak setuju pada pernyataan "Saya mengatakan hal positif mengenai XYZ”. Hal ini berarti XYZ memiliki citra yang baik.
Tabel 19. Analisis Tingkat Loyalitas Konsumen Berdasarkan Merekomendasikan Kepada Orang Lain

\begin{tabular}{lccc}
\hline \multicolumn{4}{c}{$\begin{array}{c}\text { Saya telah merekomendasikan XYZ kepada } \\
\text { orang lain (teman/kerabat/keluarga) }\end{array}$} \\
\hline \multirow{2}{*}{ Jawaban } & $\begin{array}{c}\text { Bobot } \\
\text { (x) }\end{array}$ & $\begin{array}{c}\text { Frekuensi } \\
\text { (f) }\end{array}$ & $\begin{array}{c}\text { Skor } \\
\text { (f.x) }\end{array}$ \\
\hline STS & 1 & 0 & 0 \\
TS & 2 & 2 & 4 \\
R & 3 & 14 & 42 \\
S & 4 & 26 & 104 \\
SS & 5 & 58 & 290 \\
\hline \multicolumn{1}{c}{ Total } & & $\mathbf{1 0 0}$ & $\mathbf{4 4 0}$ \\
\hline \multicolumn{2}{r}{}
\end{tabular}

Berdasarkan Tabel 19 mayoritas konsumen XYZ telah merekomendasikan XYZ kepada orang lain. Hal ini menunjukkan adanya kepuasan dan loyalitas yang dirasakan.

4) Membeli di luar lini produk atau jasa

Konsumen yang loyal umumnya tidak hanya membeli satu produk tetapi membeli lini produk lain dari perusahaan tersebut. Umumnya konsumen penasaran akan produk lain karena kepuasan sudah tercapai dan ingin mencoba hal baru yang ditawarkan perusahaan tersebut. Indikator yang digunakan pada karakteristik ini adalah ingin membeli produk lainnya di XYZ.

Tabel 20. Analisis Tingkat Loyalitas Konsumen Berdasarkan Pembelian Antarlini Produk

\begin{tabular}{lccc}
\hline \multicolumn{4}{c}{ Saya ingin membeli produk lainnya di XYZ } \\
\hline Jawaban & $\begin{array}{c}\text { Bobot } \\
(\mathrm{x})\end{array}$ & $\begin{array}{c}\text { Frekuensi } \\
(\mathrm{f})\end{array}$ & $\begin{array}{c}\text { Skor } \\
\text { (f.x) }\end{array}$ \\
\hline STS & 1 & 0 & 0 \\
TS & 2 & 0 & 0 \\
R & 3 & 12 & 36 \\
S & 4 & 35 & 140 \\
SS & 5 & 53 & 265 \\
\hline \multicolumn{1}{c}{ Total } & & $\mathbf{1 0 0}$ & $\mathbf{4 4 1}$
\end{tabular}


Berdasarkan Tabel 20 mayoritas konsumen $\mathrm{XYZ}$ ingin membeli produk lain yang dijual di XYZ. Rasa keingintahuan konsumen terhadap seluruh produk XYZ membuat konsumen ingin merasakan produk lainnya. Selain itu tidak terdapat responden yang tidak setuju atau sangat tidak setuju untuk berkeinginan membeli produk lain di XYZ. Hal ini dapat diindikasikan bahwa konsumen XYZ loyal.

Tabel 21. Analisis Tingkat Loyalitas Konsumen

\begin{tabular}{cccc}
\multicolumn{2}{c}{ XYZ } & & \\
\hline Pertanyaan & $\begin{array}{c}\text { Skor } \\
\text { Minimal }\end{array}$ & $\begin{array}{c}\text { Skor } \\
\text { Maksimal }\end{array}$ & Total \\
\hline 1 & 1 & 5 & 425 \\
2 & 2 & 5 & 430 \\
3 & 2 & 5 & 419 \\
4 & 1 & 5 & 385 \\
5 & 3 & 5 & 454 \\
6 & 2 & 5 & 440 \\
7 & 3 & 5 & 441 \\
\hline \multicolumn{4}{c}{ Persentase (\%) } \\
\hline
\end{tabular}

Berdasarkan hasil analisis tingkat loyalitas konsumen melalui 4 faktor dan 7 pernyataan dapat disimpulkan bahwa angka indeks tingkat loyalitas konsumen XYZ adalah sebesar 85,54\%. Hasil perhitungan skor tersebut adalah:

\section{Skor Tingkat Loyalitas Konsumen}

$$
\begin{aligned}
& =\frac{2994}{3500} \times 100 \% \\
& =85,54 \%
\end{aligned}
$$

Hasil penelitian menunjukkan bahwa konsumen XYZ memiliki tingkat loyalitas yang sangat tinggi terhadap XYZ. Menurut Sugiyono (2014), indeks tersebut masuk dalam kelompok sangat tinggi. Konsumen yang memiliki karakteristik konsumen loyal adalah konsumen yang ingin membeli dalam waktu dekat serta melakukan pembelian ulang. Selain itu, konsumen loyal juga ingin membeli produk yang ditawarkan, merekomendasikan kepada orang lain, mengatakan hal positif serta tidak terpengaruh untuk memilih e-commerce pesaing.

\section{Rekomendasi Strategi Untuk Meningkatkan Kepuasan Konsumen XYZ}

1) Desain pengetahuan tentang produk menarik

Desain pengetahuan tentang produk merupakan atribut penting menurut konsumen. XYZ diharapkan untuk memperhatikan kembali desain yang digunakan. Desain yang digunakan dapat berupa desain yang sederhana namun dapat menyampaikan pesan dengan baik dan jelas. Desain yang digunakan juga dapat menggunakan perpaduan font yang eye-catching serta perpaduan warnawarna dan unsur garis serta bidang yang dibuat sedemikian rupa. Hal ini akan menarik konsumen untuk melihat dan membacanya karena menggunakan desain yang menarik namun komunikatif. 
2. Karyawan melayani dengan tepat

Atribut karyawan melayani dengan tepat merupakan salah satu hal penting karena dengan pelayanan yang tepat, konsumen tidak akan merasa kecewa saat menerima barang pesanannya. Cara yang dapat dilakukan agar karyawan melayani dengan tepat adalah dengan memberikan pelatihan kerja sebelum karyawan terjun untuk berhubungan langsung dengan konsumen. Selain itu karyawan juga diharapkan untuk selalu bertindak secara hati-hati agar dapat memberikan pelayanan yang tepat sesuai dengan keinginan konsumen.

3. Harga yang dibayarkan sesuai dengan kualitas yang didapatkan

Harga merupakan salah satu indikator yang sering dijadikan tolak ukur kualitas produk bagi konsumen. XYZ diharapkan untuk memperhatikan kesesuaian harga yang dicantumkan dengan kualitas produk yang diberikan. Menurut Tjiptono, et al. (2008), terdapat delapan dimensi kualitas produk yaitu kinerja, fitur, reliabilitas, konformasi, daya tahan, serviceability, estetika, dan persepsi. Artinya, XYZ dapat memperhatikan elemen-elemen yang terdapat delapan dimensi tersebut misalnya kebersihan produk, pelengkap khusus, keamanan pengemasan, tingkat kematangannya, serta penampilan produknya.

4. Produk yang dikirimkan sesuai dengan pesanan

Produk yang dikirimkan pada konsumen tentunya harus sesuai dengan pesanan yang dibuat. Cara yang dapat digunakan agar produk yang dikirimkan sesuai dengan pesanan adalah membuat stok persediaan yang selalu bisa diperbaharui secara real time. Adanya sistem otomatis ini berfungsi untuk selalu melakukan pembaruan stok dengan sendirinya saat barang tersebut laku dijual sehingga konsumen tidak bisa lagi memasukkan produk yang sudah habis ke dalam keranjang belanja.

5. Karyawan mau mendengarkan keluhan konsumen

Cara yang dapat dilakukan agar karyawan mau mendengarkan keluhan konsumen adalah dengan menambahkan customer service, membuat frequently asked questions (FAQ), memperjelas alur pemesanan di media sosial serta aplikasi. Cara tersebut diharapkan dapat membantu mengurangi keluhan yang terjadi pada konsumen.

6. Rasa sayur atau buah sesuai dengan yang ditawarkan

Cita rasa merupakan atribut makanan yang meliputi penampakan, 
bau, rasa, tekstur, dan suhu. Rasa sayur dan buah yang belum sesuai ini bisa terjadi karena faktor quality control yang kurang baik. Umumnya sayur atau buah yang belum waktunya dipanen tetapi sudah dipanen memiliki rasa yang kurang enak. Menurut Pradipta (2014), umur panen memiliki pengaruh nyata terhadap tingkat kemanisan buah. Sayangnya buah yang dikirimkan oleh XYZ berbeda dengan yang ditawarkan di katalog promosi yang menjanjikan bahwa sayur atau buah yang ditawarkan sudah masak dan siap dimakan.

\section{KESIMPULAN DAN SARAN}

\section{Kesimpulan}

Berdasarkan hasil analisis deskriptif karakteristik konsumen di XYZ, dapat disimpulkan bahwa mayoritas konsumen $\mathrm{XYZ}$ berjenis kelamin perempuan dari generasi $\mathrm{Z}$ yang bekerja sebagai pegawai swasta. Mayoritas konsumen XYZ merupakan orang yang tinggal di Jakarta dengan pengeluaran rata-rata perbulan lebih dari Rp3.000.000. Konsumen tersebut memilih XYZ untuk membantu memenuhi kebutuhan pangannya karena XYZ membantu konsumennya dalam menghemat waktu dan tenaga terlebih di masa pandemi. Tingkat kepuasan konsumen termasuk pada kelompok sangat puas. Konsumen XYZ juga tergolong konsumen yang memiliki tingkat loyalitas yang sangat tinggi.

\section{Saran}

Berdasarkan hasil penelitian, saran yang dapat dipertimbangkan oleh XYZ antara lain adalah memperbaiki desain yang digunakan pada pengetahuan produk, memberikan pelatihan pada karyawan terutama yang berhubungan langsung dengan konsumen, dan meningkatkan kualitas layanan dan produk agar konsumen merasa bahwa harga yang dibayarkan sesuai. XYZ juga perlu untuk selalu memperbarui stok persediaan barang untuk menghindari barang habis. Hal ini bisa diterapkan pada aplikasi XYZ untuk menambah keterangan tentang stok barang dan langsung melakukan penutupan untuk tidak bisa dipesan lagi saat stok sudah habis secara otomatis. Selain itu XYZ diharapkan untuk menambah customer service dan membuat frequently asked questions (FAQ) untuk membantu konsumen yang mengalami kesulitan terutama saat ingin melakukan pemesanan serta memperketat kegiatan quality control-nya agar sayur dan buahnya sudah memiliki rasa yang enak saat dikirimkan ke konsumen. 
DAFTAR PUSTAKA

Allfarisi, Moh Yusa. (2018). Analisis tingkat kepuasan konsumen kecipir.com. Institut Pertanian Bogor Bogor.

Engel et al. (2010). Perilaku Konsumen. Edisi Keenam, jilid 1. Jakarta: Binarupa Aksara.
Herawaty, A. (2018). Loyalitas Konsumen: Peran Citra Merek Pasmira Di Gresik. Psikosains (Jurnal Penelitian dan Pemikiran Psikologi), 13(1), 17-32.

Rangkuti, Freddy (2002), Measuring Customer Satisfaction, Penerbit PT Gramedia Pustaka Utama, Jakarta Sugiyono. (2014). Metode Penelitian Pendidikan Pendekatan Kuantitatif, Kualitatif, dan R\&D. Bandung: Alfabeta. 